\title{
Current trends in robotics in education and computational thinking
}

\author{
Francisco José García-Peñalvo \\ GRIAL Research Group, Computer Science Department, \\ Research Institute for Educational Sciences, University of \\ Salamanca, Salamanca, Spain \\ fgarcia@usal.es \\ José Gonçalves \\ Instituto Politécnico de Bragança, Bragança, Portugal \\ goncalves@ipb.pt
}

\begin{abstract}
Computational thinking-related issues have had a specific track on TEEM Conference since 2016. This is the sixth edition of this track within the 2021 TEEM Conference edition. This year the papers are centered on programming and robotics, but the artificial intelligence topics increase their presence in the track.
\end{abstract}

\section{CCS CONCEPTS}

- Social and professional topics $\rightarrow$ Professional topics; Computing education; Computational thinking; • Computer systems organization $\rightarrow$ Embedded and cyber-physical systems; Robotics.

\section{KEYWORDS}

Computational thinking, robots, coding in schools, computational thinking skills and curriculum, programming, computer science in K-12, STEM, STEAM

\section{ACM Reference Format:}

Francisco José García-Peñalvo, Miguel Ángel Conde, José Gonçalves, and José Lima. 2021. Current trends in robotics in education and computational thinking. In Ninth International Conference on Technological Ecosystems for Enhancing Multiculturality (TEEM'21) (TEEM'21), October 26-29, 2021, Barcelona, Spain. ACM, New York, NY, USA, 4 pages. https: //doi.org/10.1145/3486011.3486411

\section{INTRODUCTION}

The concept of Computational Thinking (CT) became popular about fifteen years ago with Wing's famous paper in 2006 [1]. The CT is mainly rooted in pre-university education [2], from kindergartens $[3,4]$ to secondary education $[5,6]$, with significant success in primary education [7-9]. The CT is also considered in university education, but not with the same emphasis as in pre-university levels [10-12]. CT skills have been developed with technology, using robots [13-15], makers [16-18], and programming languages

Permission to make digital or hard copies of part or all of this work for personal or classroom use is granted without fee provided that copies are not made or distributed for profit or commercial advantage and that copies bear this notice and the full citation on the first page. Copyrights for third-party components of this work must be honored

For all other uses, contact the owner/author(s).

TEEM'21, October 26-29, 2021, Barcelona, Spain

(C) 2021 Copyright held by the owner/author(s).

ACM ISBN 978-1-4503-9066-8/21/10.

https://doi.org/10.1145/3486011.3486411

\author{
Miguel Ángel Conde \\ University of Leon, Leon, Spain \\ mcong@unileon.es
}

\author{
José Lima \\ Instituto Politécnico de Bragança, Bragança, Portugal \\ jllima@ipb.pt
}

[19-22], and without technology throughout the CT unplugged approach [23-25].

The main issue with the CT concept is the lack of a precise definition of CT. There are many CT-related literature reviews $[26,27]$, but there is no consensus on the definition. Moreover, many contradictions and misconceptions are derived from the different CT approaches [28, 29], mainly because the CT does not belong or is not associated with any specific subject.

Beyond the pedagogical reasons to enhance skills related to logical thinking and problem solving through CT [30], there is a clear commitment to educate future citizens in the basic knowledge of computer science as a science and technology [31,32], beyond a mere digital literacy (DL) [33, 34].

However, there is a lack of national strategy in most countries to guarantee students achieve this aforementioned basic knowledge in computer science. This situation is derived from quick policies [35] that are not the best way to face the challenges we will have as society soon regarding technology and digital transformation $[36,37]$.

From its first edition of this track at TEEM Conference in 2016 (and with the 2021 edition, there are now six editions of this track [38-42]), the objective is to encourage discussion to define the limits and usefulness of CT while defending the teaching of the basics of computer science in the context of a specific subject [43].

Besides, this CT-related track also gives visibility to research projects that develop CT skills in STEM (Science, Technology, Engineering, and Mathematics) [44, 45] and STEAM (Science, Technology, Engineering, Arts, and Mathematics) [46, 47] contexts such as for example TACCLE3 coding [48], VALS [49], W-STEM [50] or RoboSTEAM [51].

\section{TRACK ORGANIZATION}

Eight papers have been accepted in this track. The COVID-19 [5254] definitely marked and conditioned the TEEM 2020 edition. In this 2021 edition, COVID-19 is still present; however, a hybrid edition is organized, allowing both presential and virtual participation of the authors.

The accepted papers are briefly presented in the following sections. 


\subsection{Interweaving Digital Literacy with Computational Thinking}

George-Reyes et al. [55] analyze and discuss the relationship between CT and DL in a framework where technology is used for education, designing a conceptual proposal that shows its common elements. The result is an initial proposal of interweaving that addresses skills such as abstraction (critical/cognitive-informational-communication), algorithm design (critical/cognitive-informational), and communication as standard components.

\subsection{A Tool Help for Introductory Programming Courses}

Figueiredo and García-Peñalvo [56] present a tool to help the teaching and learning introductory programming, so called HTProgramming. The results of the usage of this tool in the teaching context are also introduced. The authors apply a predictive model of machine learning (neural network) of student failure based on the student's profile. The resulting tool allows teachers to effectively track the entire teaching and learning process and early identify students that are most likely to fail, allowing them to devote more time to those students and try new strategies to improve their programming skills.

\subsection{Specific Didactic Strategies Used for the Development of Computational Thinking in the Female Collective in Primary and Secondary Education: A Systematic Review Protocol}

To make a good Systematic Literature Review (SLR) $[57,58]$ it is mandatory to define the right protocol to follow the review workflow [59]. Torres-Torres et al. [60] define a systematic review protocol aimed at identifying the different strategies in the teaching and learning of computational thinking from a gender perspective, generating an alert regarding the needs of the female group in learning computational thinking and promoting gender-equitable education in this regard.

\subsection{Demonstrative educational haptic manipulator robot: A teaching aid in Mechatronics}

Pereira et al. [61] present an educational experiment, that consists of a mechatronic system applied to demonstrate concepts such as prototyping, control, haptic feedback and the use of different sensors and actuators. The already existent prototype was modified with the necessary changes to fulfill the requisites of the proposed system, being included load cells to provide measurement of the applied forces, and the robot gripper was also modified, being applied an electromagnetic actuator.

\subsection{Scenarios of the use of robotics as a support tool for teaching}

Lopez-Caudana et al. [62] show the results of approaching robotics as a support in mathematics classes, in various educational scenarios in Mexico, resulting in favorable ideas and experiences for the motivation of students, as STEAM education tools.

\subsection{RoboSTEAM project the pilot phases}

Conde et al. [63] presents the results of the pilots of the RoboSTEAM European Project [64], which have been affected by the COVID-19 pandemic [65]. The application of Challenge Based Learning and Physical Devices and Robotics facilitate the so named twenty first century skills. The results show that there are important differences between partners socioeconomical context, but that the outcomes of the project are flexible enough to be applied successfully in any of them.

\subsection{Using Educational Robotic Exoskeleton for the Acquisition of Cross-Curricular Competences in Higher Education}

Lozano-Arias et al. [66] have designed a prototype of a low-cost and open-access exoskeleton that can be used in different engineering degrees for the acquisition of cross-curricular competences. They also propose to use it in a practice to be carried out in the laboratory following the project-based learning methodology from a STEAM approach. With the use of a robotics kit and a project-based learning methodology, authors achieve the goals of educational robotics and computational thinking in a higher education environment.

\subsection{Visualization tool for teaching and learning Artificial Neural Networks}

Mrong et al. [67] describe a visualization tool for teaching and learning the basics of artificial neural networks with a user interface and a mobile robot. The study suggests that visualization tools can increase interest in teaching and learning certain topics regardless of its complexity. It also suggests that similar tools can be utilized in teaching topics related to Artificial Intelligence.

\section{REFERENCES}

[1] J. M. Wing. 2006. Computational Thinking. Communications of the ACM 49, 3, 33-35. DOI:10.1145/1118178.1118215.

[2] F. J. García-Peñalvo and J. A. Mendes. 2018. Exploring the computational thinking effects in pre-university education. Computers in Human Behavior 80, 407-411. DOI:10.1016/j.chb.2017.12.005.

[3] M. U. Bers, L. Flannery, E. R. Kazakoff, and A. Sullivan. 2014. Computational thinking and tinkering: Exploration of an early childhood robotics curriculum. Computers and Education 72, 145-157. DOI:10.1016/j.compedu.2013.10.020.

[4] Y. A. Caballero González and A. García-Valcárcel Muñoz-Repiso. 2017. Development of computational thinking and collaborative learning in kindergarten using programmable educational robots: a teacher training experience. In Fifth International Conference on Technological Ecosystems for Enhancing Multiculturality (TEEM'17) (Cádiz, Spain, October 18-20, 2017) J.M. Dodero, M.S. Ibarra Sáiz and I. Ruiz Rube Eds. ACM, New York, NY, USA, Article 5. DOI:10.1145/3144826.3145353.

[5] R. J. Toedte, M. Aydeniz, and Ieee. 2015. Computational Thinking and Impacts on K-12 Science Education. In Frontiers in Education Conference, 1323-1329.

[6] A. Yadav, C. Mayfield, N. E. Zhou, S. Hambrusch, and J. T. Korb. 2014. Computational Thinking in Elementary and Secondary Teacher Education. ACM Transactions on Computing Education 14, 1 (Mar). DOI:10.1145/2576872. 
[7] G. Chiazzese, G. Fulantelli, V. Pipitone, and D. Taibi. 2018. Engaging Primary School Children in Computational Thinking: Designing and Developing Videogames. Education in the Knowledge Society 19, 2, 63-81. DOI:10.14201/eks20181926381.

[8] C. S. González-González. 2019. State of the art in the teaching of computational thinking and programming in childhood education. Education in the Knowledge Society 20. DOI:10.14201/eks2019_20_a17.

[9] Y. A. Caballero-González and A. García-Valcárcel. 2020. ¿Aprender con robótica en Educación Primaria? Un medio de estimular el pensamiento computacional. Education in the Knowledge Society 21. DOI:10.14201/eks.21443.

[10] A. Rojas-López and F. J. García-Peñalvo. 2018. Learning scenarios for the subject Methodology of Programming from evaluating the Computational Thinking of new students. IEEE Revista Iberoamericana de Tecnologías del Aprendizaje (IEEE RITA) 13, 1, 30-36. DOI:10.1109/RITA.2018.2809941.

[11] A. Rojas-López and F. J. García-Peñalvo. 2020. Evaluación de habilidades del pensamiento computacional para predecir el aprendizaje y retención de estudiantes en la asignatura de programación de computadoras en educación superior. $R E D$. Revista de Educación a Distancia 20, 63. DOI:10.6018/red.409991.

[12] J. A. Q. Figueiredo. 2017. How to improve computational thinking: A case study. Education in the Knowledge Society 18, 4, 35-51. DOI:10.14201/eks20171843551.

[13] J. González Martínez, M. Estebanell Minguell, and M. Peracaula Bosch 2018. ¿Robots o programación? El concepto de Pensamiento Computacional y los futuros maestros. Education in the Knowledge Society 19, 2, 29-45. DOI:10.14201/eks20181922945.

[14] J. F. Álvarez-Herrero. 2020. Computational Thinking in Early Childhood Education, beyond Floor Robots. Education in the Knowledge Society 21. DOI:10.14201/eks.22366.

[15] M. Á. Conde, F. J. Rodríguez-Sedano, C. Fernández-Llamas, J. Gonçalves, J. Lima and F. J. García-Peñalvo. 2021. Fostering STEAM through Challenge Based Learning, Robotics and Physical Devices: A systematic mapping literature review. Computer Application in Engineering Education 29, 46-65. DOI:10.1002/cae.22354.

[16] F. J. García-Peñalvo, D. Reimann, and C. Maday. 2018. Introducing Coding and Computational Thinking in the Schools: The TACCLE 3 - Coding Project Experience. In Computational Thinking in the STEM Disciplines. Foundations and Research Highlights, M.S. Khine Ed. Springer, Cham, Switzerland, 213-226. DOI:10.1007/9783-319-93566-9 11

[17] D. Reimann and C. Maday. 2017. Enseñanza y aprendizaje del modelado computacional en procesos creativos y contextos estéticos. Education in the Knowledge Society 18, 3, 87-97. DOI:10.14201/eks20171838797.

[18] J. A. Rode, A. Weibert, A. Marshall, K. Aal, T. Von Rekowski, H. El Mimoni, and J. Booker. 2015. From computational thinking to computational making. In UbiComp 2015 - Proceedings of the 2015 ACM International Foint Conference on Pervasive and Ubiquitous Computing, 239-250. DOI:10.1145/2750858.2804261.

[19] N. Pellas and E. Peroutseas. 2016. Gaming in Second Life via Scratch4SL: Engaging High School Students in Programming Courses. Fournal of Educational Computing Research 54, 1 (Mar), 108-143. DOI:10.1177/0735633115612785.

[20] K. Depryck. 2016. From computational thinking to coding and back. In Proceedings of the Fourth International Conference on Technological Ecosystems for Enhancing Multiculturality (TEEM'16) (Salamanca, Spain, November 2-4, 2016), F.J. GarcíaPeñalvo Ed. ACM, New York, NY, USA, 27-29. DOI:10.1145/3012430.3012492.

[21] S. Y. Lye and J. H. L. Koh. 2014. Review on teaching and learning of computational thinking through programming: What is next for K-12? Computers in Human Behavior 41, 51-61. DOI:10.1016/j.chb.2014.09.012.

[22] A. M. Pinto-Llorente, S. Casillas-Martín, M. Cabezas-González, and F. J. GarcíaPeñalvo. 2018. Building, coding and programming 3D models via a visual programming environment. Quality \& Quantity 52, 6, 2455-2468. DOI:10.1007/s11135017-0509-4.

[23] T. Bell and J. Vahrenhold. 2018. CS Unplugged-How Is It Used, and Does It Work? In Adventures Between Lower Bounds and Higher Altitudes, H.J. Böckenhauer, D. Komm and U. W. Eds. Springer, Cham. DOI:10.1007/978-3-319-98355-4_29.

[24] M. Zapata-Ros. 2019. Computational Thinking Unplugged. Education in the Knowledge Society 20. DOI:10.14201/eks2019_20_a18.

[25] H. Montes-León, R. Hijón-Neira, D. Pérez-Marín, and R. Montes-León. 2020 Mejora del Pensamiento Computacional en Estudiantes de Secundaria con Tareas Unplugged. Education in the Knowledge Society 21. DOI:10.14201/eks.23002.

[26] F. Kalelioglu, Y. Gulbahar, and V. Kukul. 2016. A Framework for Computational Thinking Based on a Systematic Research Review. Baltic fournal of Modern Computing 4, 3, 583-596.

[27] C. Tikva and E. Tambouris. 2021. Mapping computational thinking through programming in K-12 education: A conceptual model based on a systematic literature review. Computers \& Education 162. DOI:10.1016/j.compedu.2020.104083.

[28] I. Corradini, M. Lodi, and E. Nardelli. 2017. Conceptions and misconceptions about computational thinking among Italian primary school teachers. In Proceedings of the Fourteenth Annual ACM International Computing Education Research Conference, ICER 2017 ACM, New York, USA, 136-144. DOI:10.1145/3105726.3106194.

[29] E. Nardelli. 2019. Do we really need computational thinking? Communications of the ACM 62, 2, 32-35. DOI:10.1145/3231587.
[30] S. Buckley. 2012. The Role of Computational Thinking and Critical Thinking in Problem Solving in a Learning Environment. Proceedings of the 11th European Conference on E-Learning, 63-70.

[31] A. Balanskat and K. Engelhardt. 2015. Computing our future. Computer programming and coding Priorities, school curricula and initiatives across Europe. European Schoolnet.

[32] W. Gander, A. Petit, G. Berry, B. Demo, J. Vahrenhold, A. Mcgettrick, R. Boyle, M. Drechsler, A. Mendelson, C. Stephenson, C. Ghezzi, and B. Meyer. 2013. Informatics education: Europe cannot afford to miss the boat. Report of the joint Informatics Europe \& ACM Europe Working Group on Informatics Education.

[33] J. Á. Velázquez-Iturbide, A. Bahamonde, S. Dabic, M. J. Escalona, F. Feito, S. Fernández Cabaleiro, B. Ferrero Martín, N. Garay Vitoria, J. C. García, L. García Borgoñón, M. García Martínez, J. García Molina, I. García Varea, M. Hermenegildo Salinas, E. Larraza Mendiluze, F. Llorens Largo, J. A. Mateos, A. Moratel Muñoz, D. Mozos, E. Pimentel, B. Sahelices, M. Toro, and M. Zapata Ros. 2018. Informe del Grupo de Trabajo SCIE/CODDII sobre la enseñanza preuniversitaria de la informática. Sociedad Científica Informática de España, Conferencia de Decanos y Directores de Ingeniería Informática.

[34] J. Á. Velázquez-Iturbide. 2018. Report of the Spanish Computing Scientific Society on Computing Education in Pre-University Stages. In Proceedings TEEM'18. Sixth International Conference on Technological Ecosystems for Enhancing Multiculturality (Salamanca, Spain, October 24th-26th, 2018), F.J. García-Peñalvo Ed. ACM, New York, NY, USA, 2-7. DOI:10.1145/3284179.3284180.

[35] J. Adell Segura, M. Á. Llopis Nebot, F. Esteve Mon, and M.G. Valdeolivas Novella. 2019. El debate sobre el pensamiento computacional en educación. RIED. Revista Iberoamericana de Educación a Distancia 22, 1, 171-186. DOI:10.5944/ried.22.1.22303.

[36] A. J. Argüelles, H. D. Cortés, O. E. Piñal Ramirez, and O. A. Bustamante. 2021. Technological Spotlights of Digital Transformation - Uses and Implications under COVID-19 Conditions. In Information Technology Trends for a Global and Interdisciplinary Research Community, F.J. García-Peñalvo Ed. IGI Global, Hershey PA, USA, 19-49. DOI:10.4018/978-1-7998-4156-2.ch002.

[37] F. J. García-Peñalvo. 2021. Digital Transformation in the Universities: Implications of the COVID-19 Pandemic. Education in the Knowledge Society 22. DOI:10.14201/eks.25465

[38] F. J. García-Peñalvo and J. Cruz-Benito. 2016. Computational thinking in preuniversity education. In Proceedings of the Fourth International Conference on Technological Ecosystems for Enhancing Multiculturality (TEEM'16) (Salamanca, Spain, November 2-4, 2016), F.J. García-Peñalvo Ed. ACM, New York, NY, USA, 13-17. DOI:10.1145/3012430.3012490.

[39] F. J. García-Peñalvo. 2017. Computational thinking issues. In Fifth International Conference on Technological Ecosystems for Enhancing Multiculturality (TEEM'17) (Cádiz, Spain, October 18-20, 2017) J.M. Dodero, M.S. Ibarra Sáiz and I. Ruiz Rube Eds. ACM, New York, NY, USA, Article 1. DOI:10.1145/3144826.3145349.

[40] F. J. García-Peñalvo. 2018. Computational thinking and programming education principles. In TEEM'18 Proceedings of the Sixth International Conference on Technological Ecosystems for Enhancing Multiculturality (Salamanca, Spain, October 24th-26th, 2018), F.J. García-Peñalvo Ed. ACM, New York, NY, USA, 14-17. DOI:10.1145/3284179.3284184.

[41] F. J. García-Peñalvo, M. Á. Conde, and J. Gonçalves. 2019. Computational thinking and robotics in education. In TEEM'19 Proceedings of the Seventh International Conference on Technological Ecosystems for Enhancing Multiculturality (Leon, Spain, October 16th-18th, 2019), M.Á. Conde-González, F.J. Rodríguez-Sedano, C. Fernández-Llamas and F.J. García-Peñalvo Eds. ACM, New York, NY, USA, 2-5. DOI:10.1145/3362789.3362957.

[42] F. J. García-Peñalvo, M. Á. Code, J. Gonçalves, and J. Lima. 2020. Advances in Computational thinking and robotics in education. In Proceedings TEEM'20. Eighth International Conference on Technological Ecosystems for Enhancing Multiculturality (Salamanca, Spain, October 21st - 23rd, 2020), F.J. García-Peñalvo Ed. ACM, New York, NY, USA. DOI:10.1145/3434780.3436703.

[43] F. Llorens-Largo, F. J. García-Peñalvo, X. Molero Prieto, and E. Vendrell Vidal. 2017. La enseñanza de la informática, la programación y el pensamiento computacional en los estudios preuniversitarios. Education in the Knowledge Society 18, 2, 7-17. DOI:10.14201/eks2017182717.

[44] M. S. Ramírez-Montoya (Ed.). 2017. Handbook of Research on Driving STEM Learning With Educational Technologies. IGI Global, Hershey PA, USA.

[45] F. J. García-Peñalvo, A. Bello, A. Dominguez, and R. M. Romero Chacón. 2019. Gender Balance Actions, Policies and Strategies for STEM: Results from a World Café Conversation. Education in the Knowledge Society 20, 31-31 - 3115. DOI:10.14201/eks2019_20_a31.

[46] M. H. Land. 2013. Full STEAM Ahead: The Benefits of Integrating the Arts Into STEM. Procedia Computer Science 20, 547-552. DOI:10.1016/j.procs.2013.09.317.

[47] E. Jurado, D. Fonseca, J. Coderch, and X. Canaleta. 2020. Social STEAM Learning at an Early Age with Robotic Platforms: A Case Study in Four Schools in Spain. Sensors 20, 13. DOI:10.3390/s20133698.

[48] F. J. García-Peñalvo. 2016. A brief introduction to TACCLE 3 - Coding European Project. In 2016 International Symposium on Computers in Education (SIIE 16), F.J. García-Peñalvo and J.A. Mendes Eds. IEEE, USA. DOI:10.1109/SIIE.2016.7751876. 
[49] F. J. García-Peñalvo, J. Cruz-Benito, D. Griffiths, and A. P. Achilleos. 2016. Virtual placements management process supported by technology: Proposal and firsts results of the Semester of Code. IEEE Revista Iberoamericana de Tecnologías del Aprendizaje (IEEE RITA) 11, 1, 47-54. DOI:10.1109/RITA.2016.2518461.

[50] A. García-Holgado, A. Camacho Díaz, and F. J. García-Peñalvo. 2019. Engaging women into STEM in Latin America: W-STEM project. In TEEM'19 Proceedings of the Seventh International Conference on Technological Ecosystems for Enhancing Multiculturality (Leon, Spain, October 16th-18th, 2019), M.Á. Conde-González, F.J. Rodríguez-Sedano, C. Fernández-Llamas and F.J. García-Peñalvo Eds. ACM, New York, NY, USA, 232-239. DOI:10.1145/3362789.3362902.

[51] M. Á. Conde, F. J. Rodríguez-Sedano, C. Fernández-Llamas, M. Jesus, M. J. Ramos, S. Celis-Tena, J. Gonçalves, I. Jormanainen, and F. J. García-Peñalvo. 2020. Exchanging Challenge Based Learning Experiences in the Context of RoboSTEAM Erasmus+ Project. In Learning and Collaboration Technologies. Design, Experiences 7th International Conference, LCT 2020, Held as Part of the 22nd HCI International Conference, HCII 2020, Copenhagen, Denmark, fuly 19-24, 2020, Proceedings, Part I, P. Zaphiris and A. Ioannou Eds. Springer Nature, Cham, Switzerland, 442-455. DOI:10.1007/978-3-030-50513-4_33.

[52] F. J. García-Peñalvo and A. Corell. 2020. La COVID-19: ¿enzima de la transformación digital de la docencia o reflejo de una crisis metodológica y competencial en la educación superior? Campus Virtuales 9, 2, 83-98.

[53] F. J. García-Peñalvo, A. Corell, V. Abella-García, and M. Grande-De-Prado. 2020 Online Assessment in Higher Education in the Time of COVID-19. Education in the Knowledge Society 21. DOI:10.14201/eks.23013.

[54] F. J. García-Peñalvo, A. Corell, V. Abella-García, and M. Grande-De-Prado. 2021. Recommendations for Mandatory Online Assessment in Higher Education During the COVID-19 Pandemic. In Radical Solutions for Education in a Crisis Context. COVID-19 as an Opportunity for Global Learning, D. Burgos, A. Tlili and A. Tabacco Eds. Springer Nature, Singapore, Singapore, 85-98. DOI:10.1007/978-981-15-78694_6.

[55] C. E. George-Reyes, F. J. Rocha Estrada, and L. D. Glasserman-Morales. 2021. Interweaving Digital Literacy with Computational Thinking. In Proceedings of the 9th International Conference on Technological Ecosystems for Enhancing Multiculturality (TEEM 2021) (Barcelona, Spain, October 27-29, 2021) ACM, New York, USA

[56] J. A. Q. Figueiredo and F. J. García-Peñalvo. 2021. A Tool Help for Introductory Programming Courses. In Proceedings of the 9th International Conference on Technological Ecosystems for Enhancing Multiculturality (TEEM 2021) (Barcelona, Spain, October 27-29, 2021) ACM, New York, USA.

[57] A. García-Holgado, S. Marcos-Pablos, and F. J. García-Peñalvo. 2020. Guidelines for performing Systematic Research Projects Reviews. International fournal of Interactive Multimedia and Artificial Intelligence 6, 2, 136-144. DOI:10.9781/ijimai.2020.05.005.

[58] B. Kitchenham and S. Charters. 2007. Guidelines for performing Systematic Literature Reviews in Software Engineering. Version 2.3. Technical Report Report. School of Computer Science and Mathematics, Keele University.

[59] L. Shamseer, D. Moher, M. Clarke, D. Ghersi, A. Liberati, M. Petticrew, P. Shekelle, and L. A. Stewart. 2015. Preferred reporting items for systematic review and meta-analysis protocols (PRISMA-P) 2015: elaboration and explanation. BM7 : British Medical fournal 349, g7647. DOI:10.1136/bmj.g7647.

[60] Y.-D. Torres-Torres, M. Román-González, and J.-C. Pérez-González. 2021. Specific Didactic Strategies Used for the Development of Computational Thinking in the Female Collective in Primary and Secondary Education: A Systematic Review Protocol. In Proceedings of the 9th International Conference on Technological Ecosystems for Enhancing Multiculturality (TEEM 2021) (Barcelona, Spain, October 27-29, 2021) ACM, New York, USA.

[61] A. Pereira, V. H. Pinto, J. Gonçalves, and P. Costa. 2021. Demonstrative educational haptic manipulator robot: A teaching aid in Mechatronics. In Proceedings of the 9th International Conference on Technological Ecosystems for Enhancing Multiculturality (TEEM 2021) (Barcelona, Spain, October 27-29, 2021) ACM, New York, USA.

[62] E. Lopez-Caudana, G. Rodríguez-Abitia, S. Martínez-Pérez, P. Antón-Ares, and M. S. Ramírez-Montoya. 2021. Scenarios of the use of robotics as a support tool for teaching. Challenges, learning and experiences in Mexico. In Proceedings of the 9th International Conference on Technological Ecosystems for Enhancing Multiculturality (TEEM 2021) (Barcelona, Spain, October 27-29, 2021) ACM, New York, USA.

[63] M. Á. Conde, C. Fernández-Llamas, F. J. Rodríguez-Sedano, C. GonzálezBarrientos, M. Ramos, M. Jesus, J. Gonçalves, D. Reimann, F. J. García-Peñalvo, and I. Jormanainen. 2021. RoboSTEAM project the pilot phases. In Proceedings of the 9th International Conference on Technological Ecosystems for Enhancing Multiculturality (TEEM 2021) (Barcelona, Spain, October 27-29, 2021) ACM, New York, USA.

[64] M. Á. Conde, C. Fernández-Llamas, J. F. Ribeiro Alves, M. J. Ramos, S. Celis Tena, J. Gonçalves, J. Lima, D. Reimann, I. Jormanainen, and F. J. García-Peñalvo. 2019. RoboSTEAM - A Challenge Based Learning Approach for integrating STEAM and develop Computational Thinking. In TEEM'19 Proceedings of the Seventh International Conference on Technological Ecosystems for Enhancing Multiculturality (Leon, Spain, October 16th-18th, 2019), M.Á. Conde-González, F.J. Rodríguez-Sedano, C. Fernández-Llamas and F.J. García-Peñalvo Eds. ACM, New York, NY, USA, 24-30. DOI:10.1145/3362789.3362893.

[65] M. Á. Conde, F. J. Rodríguez-Sedano, C. Ferández-Llamas, M. J. Ramos, J. Alves, S. Celis-Tena, J. Gonçalves, J. Lima, D. Reimann, I. Jormanainen, and F. J. García Peñalvo. 2020. Adaption of RoboSTEAM Project to the Pandemic Situation. In Proceedings TEEM'20. Eighth International Conference on Technological Ecosystems for Enhancing Multiculturality (Salamanca, Spain, October 21st - 23rd, 2020), F.J. García-Peñalvo Ed. ACM, New York, NY, USA. DOI:10.1145/3434780.3436620.

[66] J. Lozano-Arias, F. J. Rodríguez-Sedano, I. González-Alonso, and M. Á. Conde. 2021. Using Educational Robotic Exoskeleton for the Acquisition of Cross-Curricular Competences in Higher Education. In Proceedings of the 9th International Conference on Technological Ecosystems for Enhancing Multiculturality (TEEM 2021) (Barcelona, Spain, October 27-29, 2021) ACM, New York, USA

[67] S. Mrong, I. Jormanainen, and T. Toivonen. 2021. Visualization tool for teaching and learning Artificial Neural Networks. In Proceedings of the 9th International Conference on Technological Ecosystems for Enhancing Multiculturality (TEEM 2021) (Barcelona, Spain, October 27-29, 2021) ACM, New York, USA. 